\title{
PENGOLAHAN IKAN PATIN MENJADI PRODUK MAKANAN PATIN PRESTO, BAKSO DAN NUGGET DI SEMBORO-JEMBER
}

\author{
Oleh: \\ Ika Oktavianawati ${ }^{1}$, Niken Widya Palupi \\ 1Jurusan Kimia, FMIPA, Universitas Jember \\ 2 Jurusan Teknologi Hasil Pangan, FTP, Universitas Jember
}

\begin{abstract}
Abstrak
Kegiatan pengabdian pada masyarakat dengan skim program Ipteks bagi Masyarakat (IbM) Kelompok Petani Ikan di Desa Semboro, Kecamatan Semboro, Kabupaten Jember telah dilaksanakan. Kegiatan ini didasarkan pada eksplorasi komoditas lokal ikan patin untuk produk olahan dengan gizi tinggi dan praktisnya penanganan. Produk olahan yang dihasilkan dalam kegiatan ini diantaranya berupa patin presto, nugget dan bakso. Antusias anggota kelompok petani ikan terhadap kegiatan ini sangat positif. Namun terdapat salah satu kendala yang dihadapi kelompok petani ikan saat ini adalah kekurangtersediaan bahan ikan patin akibat kejenuhan petani dalam membudidayakan ikan patin dan juga faktor pasar. Munculnya alternatif produk olahan ikan patin ini diharapkan mampu menggugah minat masyarakat untuk melakukan pengembangan budidaya ikan patin kembali di daerah ini. Produk olahan ini juga diharapkan mampu menghilangkan kejenuhan konsumen akan produk ikan yang umumnya hanya digoreng, disup ataupun dibakar saja. Adanya produk olahan ikan patin yang praktis dan lezat untuk dinikmati akan menjadi keunggulan tersendiri dari produk ini. Diharapkan munculnya produk olahan ikan patin ini akan mampu meningkatkan nilai tambah komoditi ikan patin di wilayah Jember. Secara ekonomi, diharapkan pula taraf hidup para kelompok petani ikan di desa Semboro ini dapat meningkat.
\end{abstract}

Kata Kunci: Pengabdian Kepada Masyarakat (PKM), patin, presto, bakso, nugget

\begin{abstract}
Community service activities in science and technology program for the Community scheme (IbM) Fish Farmers Group in Semboro Village, District Semboro, Jember had been implemented. This event is based on the exploration of local commodities catfish for processed products with high nutritional and practical handling. Processed products generated in this activity in the form of catfish presto, nuggets and meatballs. Enthusiastic members of the group of fish farmers of this activity are very positive. But there is one obstacle facing a group of fish farmers today is the absence of material due to saturation catfish farmers in the cultivation of catfish and market factors. The emergence of alternative catfish processed products is expected to arouse the interest of the public to make the farming of catfish back in this area. Processed products are also expected to relieve boredom consumer goods are only fried fish, disrupt nor burned away. The presence of processed catfish products that are practical and delicious to be enjoyed will be a distinct advantage of this product. It is expected that the advent of processed catfish products will be able to increase the added value of commodities catfish in Jember. Economically, it is expected the standard of living of the group of fish farmers in the village of Semboro may increase.
\end{abstract}

Keywords: Community service activities, patin, presto, bakso, nugget

\section{PENDAHULUAN}

Ikan air tawar yang cukup populer di dunia adalah ikan patin (Kaban dan Daniel, 2005). Ikan patin jambal (Pangasius djambal) merupakan jenis ikan patin asli Indonesia yang banyak tersebar di Sumatera, Kalimantan dan sebagian Jawa (Thuy et al, 2002) dengan penampakan menyerupai lele berukuran besar. Pada usia 6 bulan, ikan ini dapat mencapai panjang $35-40 \mathrm{~cm}$. Ikan patin memiliki warna putih seperti perak, punggung warna kebiru-biruan, kepala relatif kecil, dan disudut mulutnya terdapat kumis sebagai peraba (Radar Jatim, 2013).

Ikan jenis ini diketahui memiliki tingkat kesegaran yang tinggi, penampilan dagingnya putih menarik, dengan sedikit tulang dan kulit, serta sedikit bau amis (Ariyanto dan Utami, 2006). Ikan patin secara umum memiliki kandungan protein 13,13$68,60 \%$, lemak 1,09-5,80\%, karbohidrat $1,50 \%$, abu $0,17-5,0 \%$ dan air 59,3-75,5\% (Ariyanto dan Utami, 2006; Domiszewski et 
al, 2011; Orban et al, 2008). Ikan ini juga mengandung rendah lipida (Rahardja dkk, 2011) dan kolesterol (Panagan dkk, 2011).

Berdasarkan aspek ekonominya, jenis ikan patin merupakan ikan yang cukup popular dikonsumsi di kota-kota besar, seperti Surabaya (Jawa Timur) dan kota-kota dibagian Jawa Barat. Sedangkan khususnya di daerah Jember ini, keberadaan ikan patin sukar ditemui, baik itu dalam bentuk ikan mentahnya, apalagi bentuk produk olahannya. Hal ini karena memang ikan patin masih kurang populer di masyarakat jika dibandingkan dengan ikan lele ataupun ikan gurami.

Menurut informasi dari kepala Dinas Peternakan, Perikanan dan Kelautan (Disperikel) kabupaten Jember, Mahfud Affandi, bahwa sebenarnya potensi ikan patin di Jember sangatlah besar karena ikan patin bisa dibudidayakan dengan kepadatan yang cukup tinggi (KBRN Jember, 2014). Sekitar $10 \mathrm{~kg}$ ikan patin dapat dibudidayakan bersama dalam $1 \mathrm{~m} 3$ air. Sehingga budidaya ikan patin tidak membutuhkan kolam luas. Ditambahkan pula, menurut web Antara Jatim.com (Solichah, 2015) bahwa pemerintah Kabupaten Jember saat ini terus berusaha meningkatkan budidaya ikan patin dengan membuat program pembenihan sendiri di kecamatan Rambipuji dan Kalisat dengan indukan yang berasal dari BBPBAT Sukabumi, Jawa Barat.

Selain itu pangsa pasar ikan patin di Indonesia cukup berpeluang lebar karena pemerintah pusat telah membuat kebijakan untuk membatasi impor ikan patin. Berdasarkan pengamatan pada salah satu lokasi budidaya ikan patin dimana 3000 ekor bibit ikan yang dibudidayakan selama 250 hari mampu memberi keuntungan sekitar 24,9 juta rupiah dengan rasio kematian ikan hanya sekitar $16 \%$. Informasi dari Berita Daerah Jember (2014) menyebutkan bahwa pembudidaya ikan patin yang menjual ikan patin usia tujuh bulan memiliki berat minimal ikan 800 gram dengan harga Rp 15.000/kg dapat memasok minimal 5 ton sekali kirim. Sedangkan pembudidaya ini umumnya juga mendapatkan bantuan pakan dari mitra.

Desa Semboro merupakan salah satu desa di kecamatan Semboro dengan luas wilayah $\square 952,707 \mathrm{Ha}$. Secara geografis, desa Semboro terletak pada dataran rendah dengan ketinggian rata-rata $25 \mathrm{DPL}$ yang berada di sebelah barat wilayah Jember. Berdasarkan segi topografi, desa Semboro terletak pada daerah pertanian yang subur (agraris) sehingga mayoritas penduduk di daerah ini memiliki sumber pencaharian utama sebagai petani agroindustri dan juga peternakan dan perikanan.

Khususnya dibidang perikanan, banyak terdapat kelompok petani ikan yang telah diakui dan tercatat di kecamatan Semboro. Bahkan karena melihat dari potensi Semboro sebagai daerah perikanan ini, beberapa diantara kelompok petani tersebut telah mendapatkan bantuan (hibah atau pinjaman) dan suntikan dana baik dari pemerintah maupun pihak swasta untuk mengembangkan usaha budidaya ikan air tawar. Sebagian besar dari kelompok tersebut cenderung membudidayakan jenis ikan gurami dan ikan lele karena pangsa pasar yang cukup besar dan minat konsumen yang tinggi pada kedua jenis ikan tersebut. Namun ada beberapa petani ikan yang juga berinisiatif membudidayakan ikan patin sebagai alternatif ikan budidaya karena memang telah memiliki pasar tersendiri.

Fokus utama para petani ikan di daerah Semboro ini adalah pengembangan budidaya ikan saja. Perhatian para petani pada diversifikasi produk olahan ikan untuk meningkatkan nilai tambah komoditas ini belum pernah terpikirkan sebelumnya. Padahal jika bahan mentah (ikan) tersebut diolah dengan sedikit proses saja, maka akan mampu meningkatkan nilai jual ikan tersebut.

Berdasarkan sisi aspek manajemen, terlihat bahwa sebenarnya bentuk bantuan budidaya ikan yang sudah ada sebelumnya pada para petani ikan tersebut belum dapat dimanfaatkan dengan sebaik-baiknya. Hal ini karena fokus petani hanya pada budidaya saja. Aspek manajerial dalam pengembangan pasar atau marketing tidaklah menjadi prioritas kedua bagi petani ikan tersebut untuk berkembang. Sehingga petani akan tetap mengalami ketergantungan pada pasar.

Pada faktanya bahwa budidaya ikan air tawar ini sangat tergantung pada pasar. Misalkan pada kasus ikan patin. Ikan ini kurang populer untuk dikonsumsi di daerah Jember. Sehingga harga jual ikan patin jauh lebih rendah dibandingkan ikan gurami, walaupun sedikit lebih tinggi dibandingkan ikan lele. Padahal jika dikaji, kandungan gizi ikan patin sangatlah bagus (Ariyanto dan Utami, 2006; Domiszewski et al, 2011; Orban et al, 2008) dengan tekstur daging ikan yang lebih tebal dan gurih (Ariyanto dan Utami, 2006) dibandingkan ikan gurami. Ikan patin sendiri merupakan ikan populer yang menjadi 
menu masakan spesial dibeberapa restoran di kota-kota lainnya.

Selama ini, tiap kelompok petani ikan yang memiliki anggota lima orang ini memiliki sekitar 3 kolam ikan. Ada sumber yang menyebutkan bahwa berdasarkan pengamatan pada salah satu lokasi budidaya ikan patin dimana 3000 ekor bibit ikan yang dibudidayakan selama 250 hari mampu memberi keuntungan sekitar 24,9 juta rupiah dengan rasio kematian ikan hanya sekitar 16\% (KBRN Jember, 2014).

Namun karena marketing hanya tergantung pangsa pasar, maka harga jual ikan patin ini monoton relatif rendah. Kurang populernya ikan patin di wilayah Jember juga menyebabkan daya tarik konsumen rendah dibandingkan ikan lele dan gurami. Pada faktanya ikan lele walaupun sedikit lebih murah dibandingkan ikan patin tapi memiliki tekstur daging tidak setebal dan segurih ikan patin. Harga ikan gurami yang jauh lebih tinggi sebenarnya merupakan salah satu faktor utama yang dapat dijadikan alasan agar konsumen dapat berpindah pilihan pada ikan patin.

Berdasarkan hal tersebut, maka diperlukan suatu inovasi mengenai diversifikasi produk dari ikan patin yang memiliki penampilan lebih menarik, mudah dan praktis untuk disiapkan, serta lezat untuk dinikmati. Produk olahan ikan patin juga dapat menghilangkan kejenuhan konsumen pada produk yang monoton yaitu ikan mentah yang digoreng, disup atau dibakar saja. Dengan biaya produksi pengolahan yang dapat ditekan rendah sesuai dengan proses yang diinginkan, namun mampu menghasilkan produk olahan yang menarik dan memiliki waktu simpan lebih lama akan meningkatkan prospek jual dari ikan patin. Bentuk makanan olahan dari ikan patin ini akan cocok dikonsumsi oleh orang-orang sibuk karena cepat saji namun bergizi tinggi. Bentuk olahan ikan patin yang diusulkan dalam program ini adalah patin presto (tulang dan duri lunak) serta bakso dan nugget patin. Patin presto dapat menjadi produk alternatif utama dari ikan patin yang kemungkinan dapat menyaingi keberadaan bandeng presto yang bahan mentahnya sendiri sudah memiliki harga yang cukup mahal.

\section{METODE PELAKSANAAN}

Metode pendekatan yang ditawarkan kepada kelompok petani ikan ini adalah memberikan pendidikan dan pelatihan tentang penerapan Ipteks dalam pengembangan komoditi lokal. Pengolahan ikan patin menjadi patin presto merupakan salah satu bentuk teknologi unggulan alternatif yang dapat dilakukan untuk mengatasi permasalahan mitra tersebut. Produk olahan lainnya yang dapat dirumuskan adalah bakso dan nugget patin.

Masih sedikitnya bahkan belum adanya pasar produk olahan dari ikan patin di wilayah Jember ini akan membuka peluang besar bagi kelompok petani ikan patin untuk sukses dibidang usaha ini. Harga jual produk lainnya yaitu bandeng presto adalah sekitar $\mathrm{Rp}$ 30.000 - Rp 50.000/bungkus. Namun dengan menggunakan bahan ikan patin, presto ikan ini dapat memiliki harga jual produk yang lebih rendah. Walaupun harga jual patin presto akan lebih murah dibandingkan bandeng presto, peluang pasar patin presto akan lebih tinggi karena kandungan gizi protein ikan patin cukup tinggi dan rendah lemak serta kolesterol. Produk lainnya berupa bakso dan nugget patin akan memberikan alternatif baru bagi konsumen untuk menikmati ikan patin dengan praktis dan lezat.

Upaya diversifikasi produk patin belum dikembangkan di wilayah Jember karena keterbatasan ide, kreativitas dan dana kelompok petani ikan. Motivasi pengembangan kelompok hanya terpaku pada pasar sehingga harga jual ikan patin relatif rendah. Sehingga tim pelaksana merasa perlu untuk meningkatkan kepercayaan diri masyarakat lokal dalam mengembangkan usaha budidaya dan pengolahan produk ikan patin.

Berdasarkan hasil kegiatan yang telah dilakukan hingga saat ini, produksi makanan olahan berbasis ikan patin ini dapat berlangsung secara regular. Namun, analisis pemasaran produk tersebut belum terkonsentrasikan lebih baik. Kelompok petani ikan cenderung santai saat memasarkan produknya karena alasan stok produk dapat disimpan dalam jangka waktu yang agak lama. Sehingga laju keluarnya produk tidaklah begitu cepat. Hal inilah yang menyebabkan peluang-peluang yang ada tidak dimanfaatkan lebih baik sehingga dapat hilang begitu saja. Konsumen juga rata-rata berasal dari lingkungan Semboro saja yang memang pada umumnya sudah relatif jenuh terhadap produk berbasis ikan.

Kedepannya, analisis usaha dan juga pola marketing akan dikaji lebih mendalam. Sehingga diharapkan kelompok petani ikan 
sudah tidak hanya berorientasi pada produksi produk saja, tapi juga pemasarannya. Pemasaran dapat dilakukan secara online untuk meningkatkan jumlah permintaan. Namun satu hambatan yang belum teratasi dari metode marketing alternatif online yaitu uji daya tahan produk patin jika dikirim keluar kota dan butuh waktu yang cukup lama. Lebih lanjut lagi, mengacu pada hasil kegiatan yang telah dilakukan oleh Kelompok Petani Ikan Jaya Makmur dan Mina Anugerah ini, maka tim pelaksana kegiatan berencana untuk mensosialisasikan lebih luas mengenai salah satu teknik peningkatan nilai tambah komoditas lokal ini yaitu dengan memproduksi ikan presto, nugget dan bakso ikan tergantung dengan ketersediaan jenis bahan ikan lokal yang ada.

\section{HASIL DAN PEMBAHASAN}

Adapun capaian yang diperoleh dari kegiatan ini secara detail diantaranya adalah kehadiran peserta $100 \%$; peserta dapat menerapkan ilmu pengetahuan dan teknologi, dapat mengembangkan komoditi lokal ikan patin menjadi produk yang memiliki nilai jual yang lebih tinggi, dapat mengetahui metode pemrosesan produk olahan ikan patin berbasis skala rumah tangga, dapat menggunakan peralatan pendukung dalam proses pengolahan produk patin, dapat memproduksi olahan ikan patin secara mandiri, dan dapat memasarkan produk olahan ikan patin.

Hasil yang diperoleh diharapkan dapat meningkatkan pendapatan kelompok petani ikan patin di desa Semboro, sehingga keluarganya menjadi sejahtera dan mencapai tingkat kemakmuran. Hal ini otomatis juga dapat meningkatkan pendapatan masyarakat di wilayah kecamatan Semboro. Secara umum pendapatan asli daerah (PAD) kabupaten Jember juga ikut meningkat. Jangka panjang jika pemasaran produk olahan ikan patin semakin sukses, kemungkinan besar kelompok petani ikan Jaya Makmur dan Mina Anugerah dapat memperbesar kapasitas produksi produk olahan patin serta meningkatkan kualitas budidaya ikan patin.

Salah satu kendala utama dalam kegiatan ini adalah ketersediaan bahan ikan. Sebelumnya, ikan patin cukup banyak dibudidayakan di wilayah Semboro ini. Namun satu tahun terakhir ini, antusias petani ikan di Semboro menurun terhadap budidaya ikan patin. Salah satu penyebabnya adalah rentannya daya tahan ikan terhadap penyakit, dan juga adanya permainan harga dikalangan pemasok terhadap harga dasar petani.

Selain dari kendala bahan ikan, marketing atau pemasaran juga mengambil peran cukup penting dalam produksi produk olahan ikan. Pemasaran yang baik akan mendukung kesinambungan atau kontinyuitas produksi. Produksi yang regular, secara tidak langsung akan menghasilkan peningkatan pendapatan bagi para petani ikan. Berikut gammbargambar yang terkait dengan kegiatan pengabdian ini.

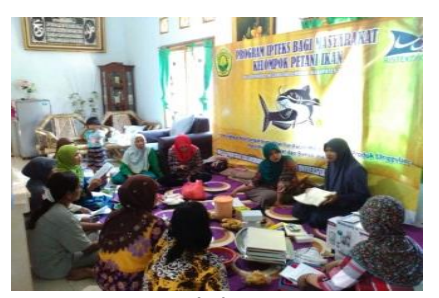

(a)

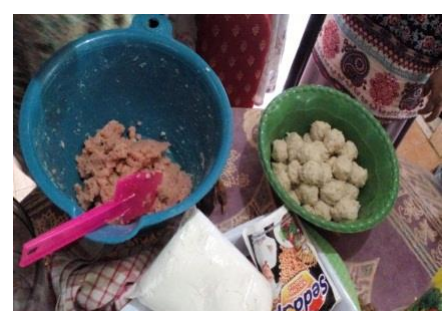

(d)

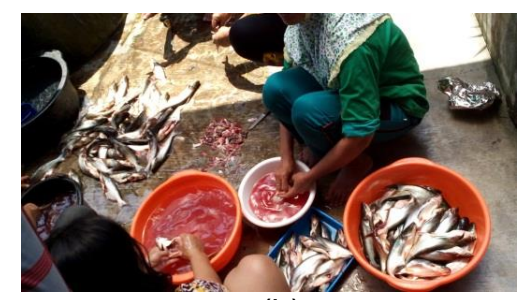

(b)

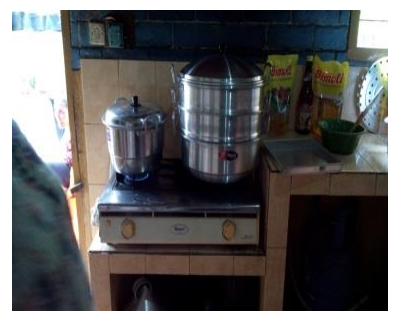

(e)

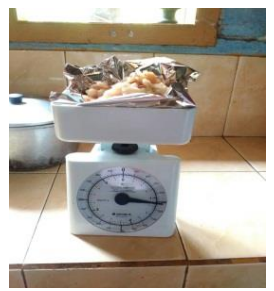

(c)

Gambar 1. (a) Kegiatan penyuluhan penerapan IPTEKS, (b) persiapan bahan ikan patin, (c) praktek pembuatan produk olahan ikan patin, (d) adonan bakso patin, (e) proses pembuatan nugget dan bakso, (f) proses pelumatan daging 


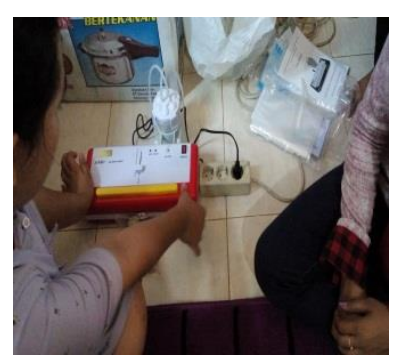

(a)

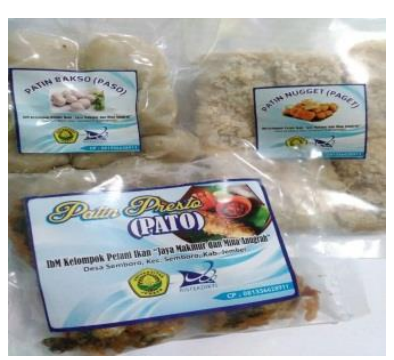

(b)

Gambar 2. (a) proses pengemasan produk, (b) produk olahan ikan patin yang telah dikemas.

\section{SIMPULAN DAN SARAN}

Berdasarkan hasil kegiatan, program IbM Kelompok Petani Ikan Desa Semboro ini dapat dinyatakan lancar dan sesuai dengan target yang telah diusulkan. Kendala utama dalam kegiatan IbM ini adalah cara marketing yang masih monoton. Namun tim pelaksana akan membantu perumusan cara marketing yang lebih baik melalui sistem marketing online.

\section{DAFTAR PUSTAKA}

Ariyanto, D., dan Utami, R., 2006, Evaluasi Laju Pertumbuhan, Keragaman Genetik dan Estimasi Heterosis pada Persilangan antar Spesies Ikan Patin (Pangasius sp.), Jurnal Perikanan, vol. VIII, no. 1, pp. 81-86.

Domiszewski, Z., Bienkiewicz, G., and Plust, D., 2011, Effects of Different Heat Treatments on Lipid Quality of Striped Catfish (Pangasius hypophthalmus), Acta Scientiarum Polonorum, Technol. Aliment., vol. 10, no. 3, pp. 359-37.

Kaban, J. dan Daniel, 2005, Sintesis n-Etil Ester Asam Lemak dari beberapa Minyak Ikan Air Tawar, Jurnal Komunikasi Penelitian, vol. 17, no. 2, pp. 16-23.

KBRN Jember, 2014, Potensi budidaya ikan patin dongkrak taraf perekonomian masyarakat Jember, RRI.co.id, 14 mei.

Orban, E., Nevigato, T., Lena, G.D., Masci, M., Casini, I., Gambelli, L., and
Caproni, R., 2008, New Trend in the Seafood Market. Sutchi Catfish (Pangasius hypopthalmus) Filet from Vietnam: Nutritional Quality and Safety Aspect, Food Chemistry, vol. 110, no. 2, pp. 383-389.

Panagan, A.T., Yohandini, H., dan Gultom, J.A., 2011, Analisis Kualitatif dan Kuantitatif Asam Lemak Tak Jenuh Omega-3 dari Minyak Ikan Patin (Pangasius pangasius) dengan Metode Kromatografi Gas, Jurnal Penelitian Sains, vol. 14 , no. 4c, pp. 14409-38 - 14409-42, Oktober 2011.

Radar Jatim, 2013, Cara budidaya ikan patin modern dan cepat panen, 26 Agustus.

Rahardja, B.S., Sari, D., Alamsjah, M.A., 2011, Pengaruh Penggunaan Tepung daging Bekicot (Achatina fulica) pada Pakan Buatan terhadap Pertumbuhan, Rasio, Konversi Pakan dan Tingkat Kelulushidupan Benih Ikan Patin (Pangasius pangasius), Jurnal IImiah Perikanan dan Kelautan, vol. 3, no. 1, pp. 117-122.

Solichah, Z., 2015, Pemkab Jember tingkatkan budidaya ikan patin, Antarajatim.com, 18 April.

Thuy, N.T., Loc, N.T., Linberg, J.E., and Ogle, B., 2002, Survey of the production, processing and nutritive value of catfish by-product meals in the Mekong Delta of Vietnam, Louisiana Agriculture 